\title{
EVALUASI PENGGUNAAN ANTIBIOTIK PADA PASIEN BALITA DENGAN DIAGNOSA ISPA BUKAN PNEUMONIA DI PUSKESMAS BOGOR TIMUR
}

\author{
Sudrajat Sugiharta, Febrian Hevike Filosane, Haviana \\ Politeknik Meta Industri Cikarang
}

\begin{abstract}
ABSTRAK
Penyakit ISPA (Infeksi Saluran Pernafasan Akut) merupakan suatu masalah kesehatan utama di Indonesia karena masih tingginya angka kejadian ISPA terutama pada anak - anak dan balita. Salah satu penyakit ISPA adalah ISPA bukan pneumonia. Berdasarkan rekomendasi WHO (World Health Organization) penanganan ISPA bukan pneumonia pada balita cukup dengan pengobatan supportif dan tidak perlu pemberian antibiotik. Dinas Kesehatan Provinsi Jawa Barat melakukan pengawasan terhadap penggunaan antibiotik di tiap Puskesmas, dimana penggunaan antibiotik di tiap Puskesmas mempunyai indikator kesalahan dari peresepan antibiotik tersebut yaitu $\leq 20 \%$. Berdasakan hal tersebut, dilakukan penelitian mengenai evaluasi penggunaan antibiotik pasien balita dengan penyakit ISPA bukan pneumonia di Puskesmas Bogor Timur. Penelitian ini menggunakan desain penelitian desktriptif non analitik terhadap data sekunder berupa rekam medis dan resep obat. Pengambilan data secara prospektif dan diperoleh 223 sampel data untuk analisis deskriptif. Hasil penelitian menunjukkan bahwa ISPA bukan pneumonia banyak terjadi pada umur $>1$ tahun - $\leq 3$ tahun yaitu 42,22\%, dengan jenis kelamin laki - laki terbanyak yaitu 54,26\%, tanda dan gejala yang dialami oleh pasien yaitu batuk dan pilek dengan data sebesar 49,33 $\%$. Diagnosa dan jenis penyakit yang dialami pasien yaitu ISPA bukan pneumonia 81,33\%, faringitis $15,11 \%$, dan common cold $8,56 \%$. Persentase penggunaan antibiotik mencapai $18,83 \%$ meski persentase mendekati angka indikator namun hal ini menunjukkan bahwa hasil penelitian masih memenuhi standar indikator kesalahan penggunaan antibiotik yaitu $\leq$ $20 \%$.
\end{abstract}

Kata Kunci: ISPA, ISPA bukan pneumonia, balita, antibiotik

\begin{abstract}
Acute Respiration Infection (ARI) is a main healthy-problem in Indonesia, because the highly record of casus, especially which infected to the children and baby. ARI which isn't Pneumonia, based on World Health Organization's recommendation about the handling of Acute Respiration Infection isn't Pneumonia to the babies and enough with supportive medication and it isn't necessary to give antibiotic. Health Department of West Java province has controlled the using of antibiotic in every PHC, where the antibiotic consumers has their own fail-indicator from the abosorbing process, which about $\leq 20 \%$. According to the data, a research has been done to evaluate the using of antibiotic for baby, which Acute Respiration Infection which isn't Pneumonia at East Bogor Public Health Center. The research used the nonanalytic descriptive design toward secondary data as medical record and medical recipe. Prospective data has been gotten by 233 samples of data for descriptive analysis. The result showed that Acute Respiration Infection isn't Pneumonia which injured the children on $>1$ years old $-<3$ years old, 42,22\%, with the male gender as majority,
\end{abstract}


which about 54,22\% . sign and symptom which mostly happened is cough and head cold, the percentage is about 49,33\%. The diagnose and type of disease which injured the patients that Acute Respiration Infection isn't Pnueumonia, the percentage is about 81,33\%, fragnitic $15,11 \%$, and common cold $8,56 \%$. The percentage of antibiotic usage reached $18.83 \%$ although the percentage is near with indicator number but this figure out that the result of research still fulfill standard of antibiotic usage error indicator that is $\leq 20 \%$.

\section{Keywords: ARI, ARI isn't pneumonia, children under 5 years old, antibiotics}

\section{PENDAHULUAN}

Penyakit ISPA (Infeksi Saluran Pernafasan Akut) merupakan suatu masalah kesehatan utama di Indonesia karena masih tingginya angka kejadian ISPA terutama pada anak-anak dan balita. Penyakit ini sangat rentan terjadi pada balita disebabkan sistem kekebalan tubuh balita mudah lebih rendah dibandingkan dengan orang dewasa dan mudah menurun. (WHO, 2007) Berdasarkan penelitian yang dilakukan oleh Triska mengenai kunjungan berobat pasien ISPA di Puskesmas sebanyak 40-60\% (Tritunggariani, 2011). Salah satu penyakit ISPA adalah ISPA bukan pneumonia atau yang lebih dikenal dengan influenza. Berdasarkan rekomendasi WHO (World Health Organization) penanganan ISPA bukan pnemonia pada balita cukup dengan pengobatan supportif dan tidak perlu pemberian antibiotik. Penelitian sebelumnya yang dilakukan Bambang Sutrisna (2003) juga menemukan bahwa tak ada perbedaan yang bermakna antara kelompok anak ISPA bukan pnemonia yang mendapat pengobatan ampisilin ditambah supportif dibanding dengan kelompok yang hanya mendapat pengobatan supportif. Selain itu, peresepan antibiotik yang cukup tinggi dan kurang tepat akan meningkatkan kejadian resistensi.

Penggunaan antibiotik yang tidak perlu atau berlebihan mendorong berkembangnya resisten dan multiple resisten terhadap bakteri tertentu yang akan menyebar melalui infeksi silang. Dimana dampak resistensi terhadap antibiotik adalah meningkatnya morbiditas, mortalitas, dan biaya kesehatan. Penggunaan antibiotik yang terkendali dapat mencegah munculnya resistensi dan menghemat penggunaan antibiotik yang pada akhirnya akan mengurangi beban biaya perawatan pasien, mempersingkat lama perawatan serta meningkatkan kualitas pelayanan rumah sakit maupun puskesmas (Kemenkes RI, 2011).

Secara klinis resistensi yang di dapat merupakan hal yang serius, dimana bakteri yang pernah sensitif terhadap suatu obat menjadi resisten. Resistensi silang juga dapat terjadi antara obat-obat antibiotik yang mempunyai kerja yang serupa (Neal, 2006).

Ketidakrasionalan penggunaan obat banyak sekali terjadi pada penderita ISPA bukan pneumonia (umumnya disebabkan oleh virus) pada anak umumnya mendapatkan antibiotik yang sebenarnya tidak diperlukan. Hal ini merupakan peresepan berlebih (overprescribing) yaitu pemberian obat yang sebenarnya tidak diperlukan untuk penyakit yang bersangkutan. Sebaliknya pada anak yang jelas menderita pneumonia justru tidak mendapatkan terapi yang adekuat. Dengan demikian angka kematian bayi dan balita akibat ISPA masih cukup tinggi di Indonesia (Kemenkes, 2011).

Dinas Kesehatan Provinsi Jawa Barat melakukan pengawasan terhadap penggunaan antibiotik di tiap Puskesmas yang terdapat pada buku Instrumen Akreditasi Puskesmas yang diterbitkan oleh Tim akreditasi Puskesmas Dinas Kesehatan Provinsi Jawa Barat tahun 2011. Penggunaan antibiotik di tiap Puskesmas mempunyai indikator kesalahan dari peresepan antibiotik tersebut yaitu $\leq 20 \%$ (Dinkes, 2011). ISPA bukan pneumonia umumnya disebabkan oleh virus, sehingga untuk terapi pengobatannya tidak memerlukan antibiotik. Maka dari itu, perlu dilakukan evaluasi penggunaan antibiotik pada penyakit ISPA bukan pneumonia yang dapat diketahui dengan melihat resep obat dan rekam medis pasien ISPA bukan pneumonia. Kemudian dihitung persentase dari penggunaan antibiotik tersebut dan dibandingkan dengan indikator kesalahan penggunaan antibiotik di Puskesmas. 


\section{METODE PENELITIAN}

Penelitian ini merupakan studi deskriptif non-analitik untuk mengevaluasi penggunaan antibiotik pada balita penyakit ISPA bukan pneumonia. Data diambil secara prospektif di Puskesmas Bogor Timur periode Februari 2014 - Maret 2014. Data yang diambil berupa data sekunder yaitu data dari rekam medis pasien serta resep obat di Puskesmas Bogor Timur. Sampel pada penelitian ini adalah pasien balita dengan diagnosa ISPA bukan pneumonia, dengan teknik pengambilan sampel yaitu dengan random sampling dengan kriteria inklusi yaitu pasien balita dengan diagnosa penyakit ISPA bukan pneumonia yang berobat di Puskesmas Bogor Timur. Sedangkan yang termasuk kriteria eksklusi adalah pasien dengan data rekam medis yang tidak lengkap. Penelitian ini dilakukan untuk mengkaji demografi pasien, gejala klinis pasien, terapi yang diberikan terhadap pasien, dan pemakaian antibiotik pada pasien balita penyakit ISPA bukan pneumonia di Puskesmas Bogor Timur. Serta melihat kesesuaian terhadap standar indikator di Puskesmas yang ditetapkan oleh Dinas Kesehatan Jawa Barat.

Data pasien diambil dari rekam medis meliputi keluhan, diagnosa, demografi pasien, obat-obat yang digunakan termasuk penggunaan antibiotik meliputi dosis, cara penggunaan, dan kesesuaian berdasarkan indikasi, hasil disajikan dalam bentuk persentase dan gambaran yang disertai tabel atau grafik.

Data hasil penelitian akan dianalisis secara deskriptif dengan penyajian dalam bentuk gambaran yang disertai dengan tabel distribusi dan grafik meliputi persentase penggunaan antibiotik, golongan antibiotik, dan kesesuian dosis antibiotik yang diberikan, serta dosis obat-obat yang diberikan kepada pasien kemudian dibandingkan dengan data persentase kesalahan penggunaan antibiotik di puskesmas.

\section{HASIL DAN PEMBAHASAN}

Pengamatan rekam medis dilakukan dengan mengambil terlebih dahulu resep obat yang diterima. Kemudian dari data resep obat dicatat nomor rekam medis untuk melakukan pengamatan terhadap rekam medis. Pengamatan rekam medis dilakukan dengan mengambil data seluruh pasien balita ISPA bukan pneumonia periode Februari 2014 - Maret 2014 sebanyak 350 pasien yang kemudian dipilih untuk dijadikan sampel penelitian. Peneliti memilih pasien balita yang akan dijadikan sampel pada penelitian sebanyak 223 pasien balita dengan kriteria antara lain pasien yang baru masuk pada bulan Februari 2014 - Maret 2014 dengan diagnosa penyakit ISPA bukan Pneumonia

\section{Demografi Pasien}

Pada penelitian ini, demografi pasien yang diamati yaitu jenis kelamin, umur, dan berat badan dari pasien ISPA bukan pneumonia di Puskesmas Bogor Timur periode Februari 2014 - Maret 2014. Dimana hasil penelitian dapat dilihat pada Tabel berikut :

Tabel 1. Distribusi proporsi demografi pasien

\begin{tabular}{|c|l|c|}
\hline Demografi pasien & \multicolumn{1}{|c|}{ Kategori } & Jumlah (\%) \\
\hline \multirow{3}{*}{ Jenis Kelamin } & Laki -Laki & $121(54,26 \%)$ \\
\cline { 2 - 3 } & Perempuan & $102(45,74 \%)$ \\
\hline \multirow{3}{*}{ Umur } & $0-1$ tahun & $72(32,28 \%)$ \\
\cline { 2 - 3 } & $>1$ tahun-3 tahun & $91(40,81 \%)$ \\
\cline { 2 - 3 } & $>3$ tahun -5 tahun & $60(26,91 \%)$ \\
\hline \multirow{3}{*}{ Berat Badan } & $<10 \mathrm{~kg}$ & $105(47,08 \%)$ \\
\cline { 2 - 3 } & $10-15 \mathrm{~kg}$ & $102(45,74 \%)$ \\
\cline { 2 - 3 } & $>15 \mathrm{~kg}$ & $16(7,18 \%)$ \\
\hline
\end{tabular}


Berdasarkan tabel di atas, pasien ISPA bukan pneumonia didominasi oleh balita jenis kelamin laki-laki, umur pada usia balita $>1$ tahun - 3tahun, dan sebagian besar memiliki berat badan $<10 \mathrm{~kg}$.

\section{Tanda dan Gejala Pasien}

Tanda dan gejala yang dialami oleh pasien balita ISPA bukan pneumonia yaitu batuk, pilek dan badan panas atau disebut dengan demam. Hasil penelitian menunjukkan bahwa pasien ISPA bukan pneumonia di Puskesmas Bogor Timur periode Februari 2014-Maret 2014 , data terbanyak yaitu gejala batuk dan pilek yaitu dengan persentase 49,33\%, diikuti dengan tanda dan gejala pasien batuk, pilek dan demam yaitu dengan persentase $44,84 \%$ seperti dapat dilihat pada gambar 8. Untuk waktu lama pasien mengalami batuk dan pilek tersebut di rekam medis yang tertulis data terbanyak batuk dan pilek yang berlangsung selama 3 hari, diikuti dengan 2 hari, dan 5 hari, bahkan ada yang mengalami batuk dan pilek selama 1 minggu.

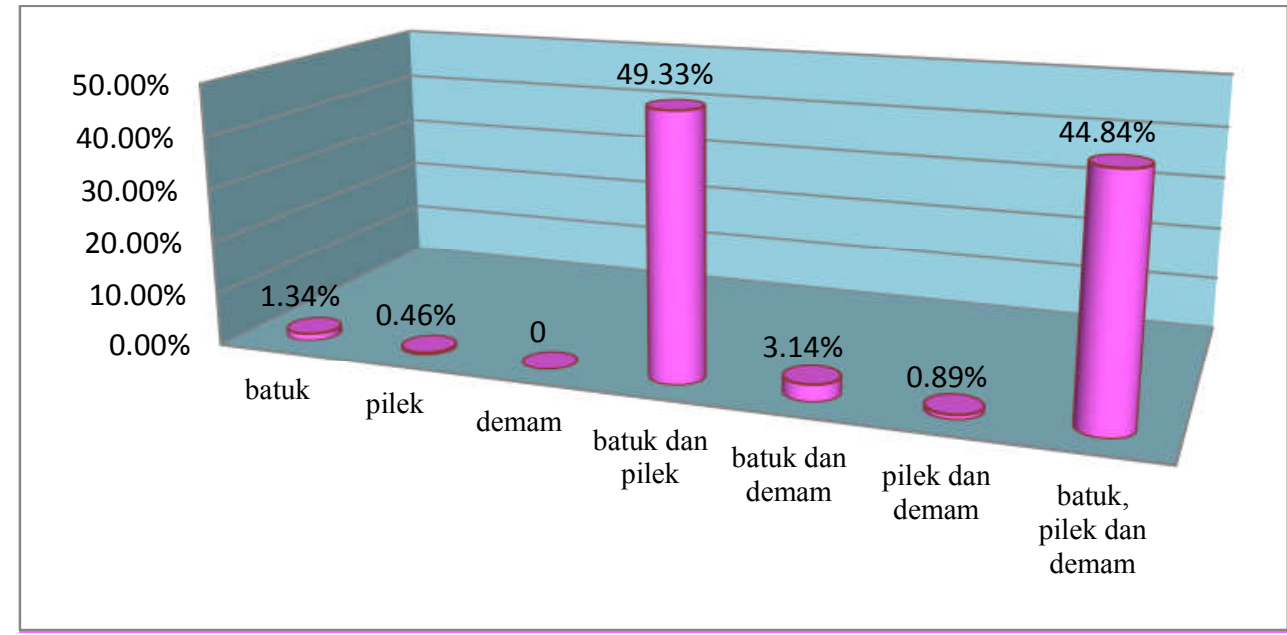

\section{Gambar 1. Grafik Frekuensi pasien balita penderita ISPA bukan Pneumonia berdasarkan Tanda dan Gejala}

Berdasarkan penelitian yang dilakukan Nasution (2005) gejala ISPA yng dialami pasien yaitu pilek $(87,8 \%)$ dan batuk kering $(71,4 \%)$ serta penelitian yang dilakukan Napitupulu dkk (2004) gejala yang paling sering ditemukan adalah pilek $(87,8 \%)$ dan batuk kering (71,4\%). Penelitian Sikolia dkk (2002) mendapatkan gejala demam, pilek, dan batuk sebagai gejala ISPA tersering pada balita.

Tanda dan gejala yang dialami pasien ini sangat mempengaruhi terhadap diagnosa pasien dan terapi pengobatan terhadap pasien. Dalam penelitian ini menunjukkan bahwa pasien mengalami tanda dan gejala dari penyakit ISPA bukan pneumonia (atau yang lebih kita kenal dengan sebutan batuk, pilek). Terdapat gejala lain yang dialami oleh pasien ISPA bukan pneumonia yaitu kesukaran menelan air liur, serta ada yang mengalami muntahmuntah, susah makan, dan diare. Hal ini menunjukkan adanya penyakit penyerta yang terdapat pada pasien.

\section{Diagnosa ISPA dan Jenis Penyakit}

Klasifikasi bukan pneumonia mencakup kelompok penderita balita dengan batuk yang tidak menunjukkan gejala peningkatan frekuensi napas dan tidak menunjukkan adanya tarikan dinding dada bagian bawah ke dalam. Dengan demikian klasifikasi bukan pneumonia 
mencakup penyakit-penyakit ISPA lain diluar pneumonia seperti batuk pilek bukan pneumonia (common cold, faringitis, tonsillitis, otitis) (Dit.Jen.PPM-PLP, 2002).

Berdasarkan hasil wawancara dengan penulis resep mengenai penulisan diagnosa yang hanya menuliskan ISPA, ISPA yang dimaksudkan adalah ISPA bukan Pneumonia. Hasil penelitian menunjukkan bahwa $81,61 \%$ dengan diagnosa ISPA bukan pneumonia, $14,80 \%$ dengan diagnosa faringitis, $3,59 \%$ dengan diagnosa common cold .

Distribusi Pasien menurut Jenis Penyakit ISPA bukan Pneumonia di Puskesmas Bogor Timur Periode IBebarbakin

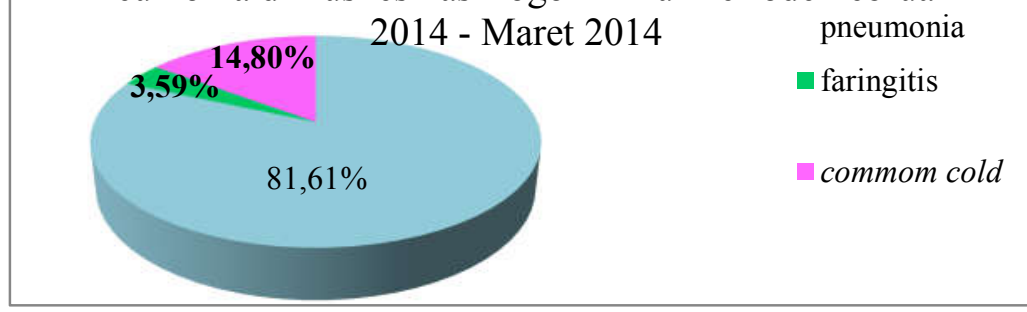

Gambar 2. Grafik distribusi pasien menurut jenis penyakit ISPA bukan Pneumonia

Berdasarkan hasil penelitian Litbangkes Depkes RI pada pasien balita dari seluruh Indonesia menunjukkan bahwa jenis ISPA terbanyak ialah bukan pneumonia yaitu 97,6\% (Depkes, 2007). Hal ini menunjukkan bahwa penderita ISPA terbanyak jenis penyakitnya yaitu ISPA bukan pneumonia.

\section{Evaluasi Penggunaan Antibiotik}

Indikasi penggunaan antibiotik adalah apabila suatu penyakit yang terjadi disebabkan oleh adanya infeksi bakteri,penyebab infeksi dengan gejala klinik ringan tidak perlu segera mendapatkan antibiotik (Gunawan, 2011). Dalam pedoman tatalaksana pasien ISPA Depkes RI (2005) dan Panduan Pelayanan Medis Departemen Ilmu Kesehatan Anak RSUP DR.Ciptomangunkusumo bahwa pasien anak dengan gejala klinik ringan seperti demam disertai batuk, pilek kurang lebih selama tiga hari tidak perlu mendapatkan antibiotik dan untuk kondisi klinis yang ringan pasien hanya perlu terapi penunjang seperti multivitamin, obat analgetik- antipiretik, dan dekongestan.

Batuk-pilek atau penyakit lain yang disebabkan oleh virus, tidak membutuhkan antibiotik untuk pengobatannya (BPOM RI, 2011). Batuk-pilek sering dialami oleh anak pada umumnya dan terjadi setiap $8-12$ kali setiap tahun. Menurut guideline CDC (Centers for Disease Control and Prevention), pengobatan antibiotik pada ISPA hanya perlu diberikan pada 20\% kasus (CDC, 2003). Hal tersebut ditetapkan berdasarkan hasil penelitian yang menunjukkan bahwa hanya 19,4\% ISPA yang disebabkan oleh bakteri dan hanya sinusitis serta pneumonia yang seharusnya ditatalaksana dengan antibiotik. CDC menyatakan bahwa indikasi pemberian antibiotik adalah bila batuk dan pilek berkelanjutan selama lebih dari 14 hari, yang terjadi sepanjang hari (bukan hanya pada malam hari dan pagi hari).

\section{Persentase Penggunaan Antibiotik}

Dalam penelitian ini, gejala umum yang terjadi pada penyakit ISPA bukan Pneumonia yaitu batuk, pilek yang disertai dengan adanya demam. Dari data penelitian tidak ada tanda dan gejala yang signifikan yang menunjukkan bahwa pasien ISPA bukan Pneumonia membutuhkan pengobatan dengan antibiotik.

Dari hasil penelitian terbukti bahwa penggunaan antibiotik untuk penanganan penyakit ISPA bukan pneumonia pada periode Februari 2014-Maret 2014 masih terjadi di Puskesmas Bogor Timur dan angka kejadiannyapun mendekati angka indikator kesalahan 
penggunaan antibiotik yaitu $18,83 \%$. Hal ini terjadi dikarenakan ISPA bukan pneumonia adalah salah satu penyakit menular yang belum menjadi fokus monitoring oleh Departemen Kesehatan dan Puskesmas Bogor Timur. Berbeda dengan kasus diare, ISPA pneumonia, Tuberkulosis, dan lainnya. Sehingga masih terjadinya penggunaan antibiotik pada ISPA bukan pneumonia (umumnya disebabkan virus) yang seharusnya tanpa menggunakan terapi antibiotik.

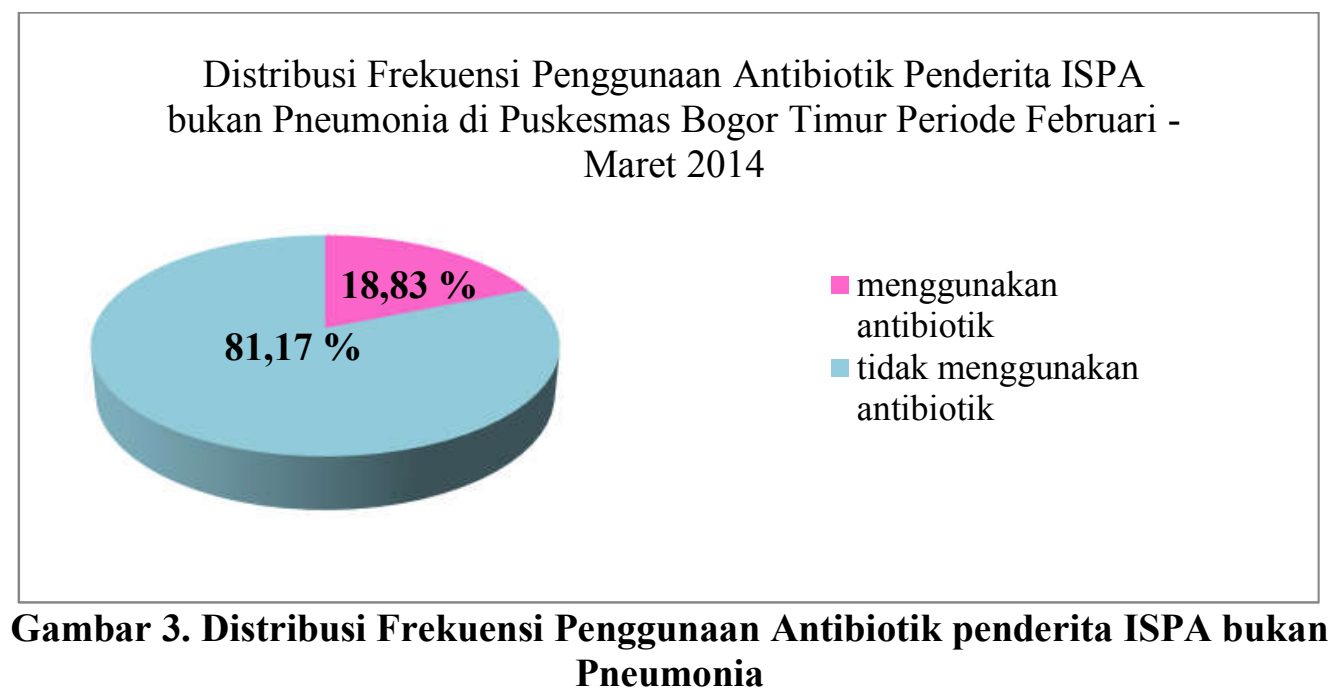

Hasil penelitian menunjukkan bahwa pemberian antibiotik pada pasien balita ISPA bukan pneumonia pada periode Februari 2014-Maret 2014 dari 223 pasien, yang menggunakan antibiotik yaitu sebanyak 42 pasien dengan persentase sebesar $18,83 \%$ (Gambar 3). Hal ini menunjukkan bahwa hasil penelitian masih memenuhi standar indikator kesalahan penggunaan antibiotik yaitu $\leq 20 \%$, yang terdapat pada Instrumen indikator Puskesmas yang dikeluarkan oleh Departemen Kesehatan.

\section{Jenis Antibiotik}

Penggunaan antibiotik terbanyak menurut golongan adalah golongan penisilin yaitu amoksisilin pada 33 pasien sebesar 78,57\% diikuti dengan kotrimoksazol pada 9 pasien yaitu $21,43 \%$

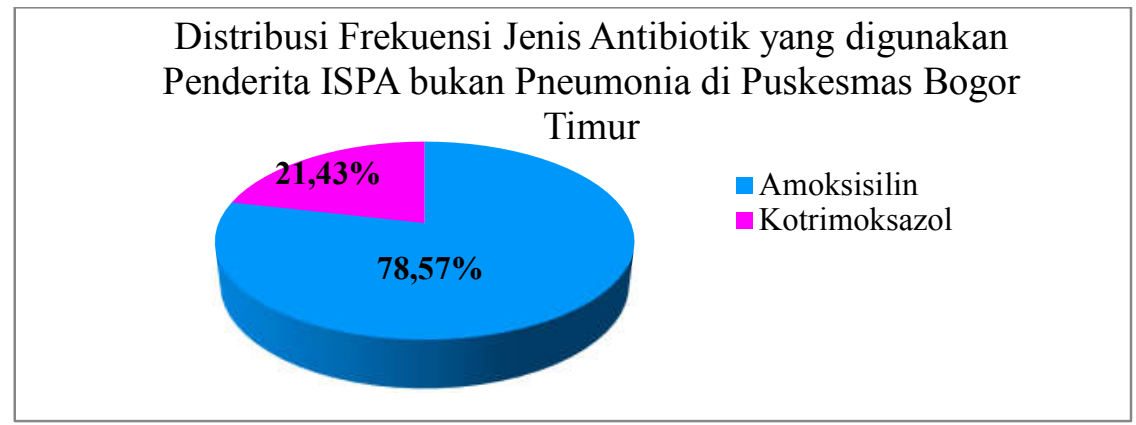

\section{Gambar 4. Distribusi Frekuensi Jenis Antibiotik Penderita ISPA bukan Pneumonia}

Amoksisilin dan kotrimoksazol adalah antibiotik yang paling banyak digunakan di Puskesmas Bogor Timur. Amoksisilin adalah antibiotik golongan penisilin yang paling efektif dan paling luas digunakan. Penisilin bebas dari sifat toksik, kebanyakan efek-efek yang tidak diinginkan yang parah terjadi karena hipersensitivitas. Penisilin merupakan salah satu antibiotik yang paling sering digunakan secara salah dan berlebihan, kotrimoksazol 
merupakan salah satu kelas sulfonamide, yaitu merupakan kombinasi trimetoprim dan sulfametoksazol yang sering digunakan untuk pengobatan infeksi paru (Katzung, 2004)

Dari hasil penelitian, data diperoleh penggunaan antibiotik secara umum yang digunakan lebih banyak adalah antibiotik dengan bentuk sediaan cair yaitu suspensi dan sirup yakni sebesar 76,19\% (Gambar 5 dan Gambar 6).

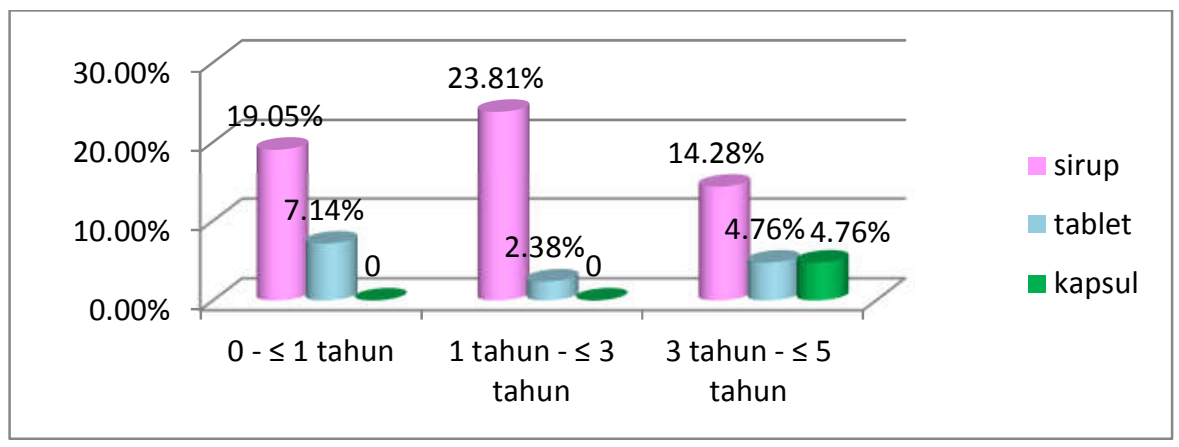

Gambar 5. Grafik Distribusi Frekuensi Pemakaian Antibiotik amoksisilin berdasarkan Bentuk Sediaan pada Pasien ISPA bukan Pneumonia.

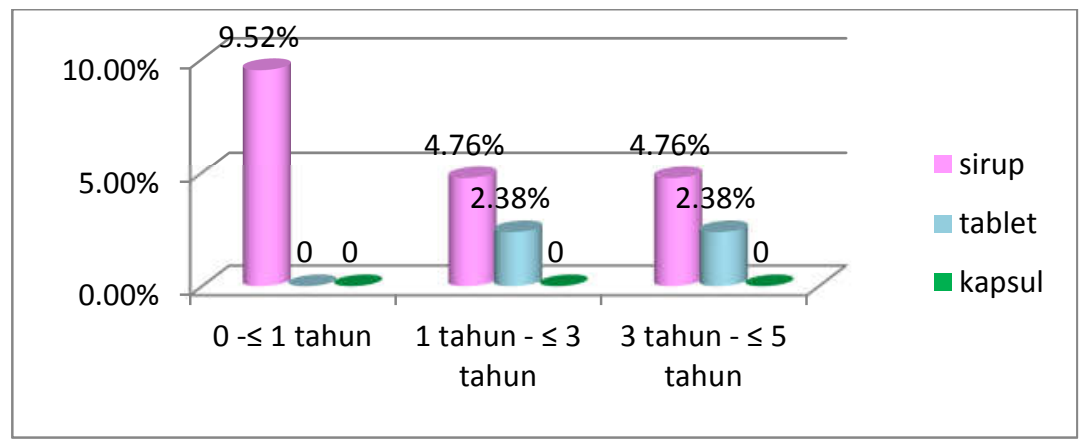

\section{Gambar 6. Grafik Distribusi Frekuensi Pemakaian Antibiotik Kotrimoksazol berdasarkan Bentuk Sediaan pada Pasien ISPA bukan Pneumonia}

Berdasarkan hasil penelitian sediaan sirup lebih banyak digunakan dibandingkan suspensi. Dikarenakan antibiotik yang digunakan lebih banyak amoksisilin dibandingkan kotrimoksazol. Sedangkan sediaan tablet dan kapsul di dalam resep data penelitian ini disajikan dalam bentuk racikan, terkecuali antibiotik kotrimoksazol. Hal ini menunjukkan bahwa antibiotik dalam sediaan cair lebih banyak digunakan dibandingkan sediaan padat. Hal ini disebabkan oleh faktor pasien yaitu balita lebih menyukai sediaan cair. Dikarenakan sirup merupakan larutan gula jenuh sehingga lebih disenangi anak, disamping manis, biasanya sirup ditambahkan rasa dan aroma yang sesuai dengan selera anak.

\section{Kesesuaian Dosis Antibiotik}

Dari penelitian ini pasien balita ISPA bukan pneumonia yang menggunakan antibiotik yang sesuai yaitu 33,33\% (Gambar 7). 


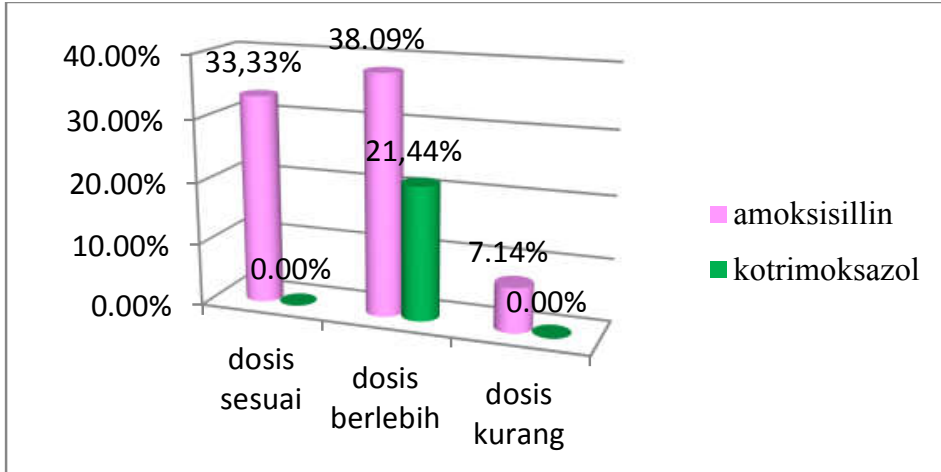

Gambar 7. Grafik distribusi Frekuensi Kesesuaian Dosis Penggunaan Antibiotik Pada Pasien ISPA bukan Pneumonia

Perhitungan dosis yang diberikan kepada pasien berdasarkan dosis lazim dan dosis maksimumnya. Dosis lazim dan maksimum untuk anak dengan antibiotik amoksisilin berdasarkan buku Farmakologi dan Terapi yaitu 20 - 40 mg / Kg BB / hari (tiap 3 dosis) dan antibiotik kotrimoksazol berdasarkan buku British National Formulary for children yaitu 24 $\mathrm{mg} / \mathrm{Kg}$ BB dalam 2 dosis (BMJ Group, 2009).

Frekuensi pemberian yang kurang rasional yaitu sebesar 66,66 \%, dimana 59,52\% merupakan pemberian antibiotik dengan dosis melebihi dosis maksimal untuk sehari pemakaian, dan sebesar 7,14\% pemberian antibiotik dengan dosis kurang dari dosis maksimalnya untuk sehari pemakaian. Perhitungan yang digunakan untuk menghitung kesesuaian dosis berdasarkan berat badan pasien.

Berdasarkan hasil penelitian, diperoleh data terbanyak yaitu dosis yang tidak sesuai yaitu dosis berlebih dengan nilai persentase sebanyak 59,53 \%. Hal ini dikarenakan ketepatan dari penulis resep yang kurang sesuai dalam memberikan dosis obat antibiotik. Pada penggunaan antibiotik berlebih perlu diwaspadai terjadinya efek samping yaitu superinfeksi.

Meskipun pada hasil yang didapat ternyata terdapat dosis antibiotik yang berlebih untuk antibiotik golongan penisilin yaitu amoksisilin, efek samping yang mungkin ditimbulkan tidak terlalu besar, karena efek samping dari penisilin tergantung dari sediaan dan cara pemberian. Pada umumnya pemberian oral lebih jarang menimbulkan efek samping daripada pemberian parenteral. Efek samping yang banyak terjadi dari golongan penisilin yaitu reaksi alergi, yang mana reaksi alergi ini terjadi dikarenakan adanya sensitasi. Walaupun pasien belum pernah menggunakan antibiotik penisilin namun mereka mengalami alergi, hal ini diduga dikarenakan sensitasi terjadi akibat pencemaran lingkungan oleh penisilin (misalnya makanan asal hewan atau jamur) (Gunawan, 2011).

Pertimbangan resiko dan manfaat harus diutamakan dalam menentukan obat antiinfeksi yang akan diberikan kepada pasien. Keberhasilan pengobatan tidak terlepas dari pertimbangan klinis, tetapi juga dipengaruhi oleh beberapa faktor yang salah satunya adalah dosis obat harus cukup tinggi dan efektif terhadap mikroorganisme, namun konsentrasi di dalam plasma dan jaringan tubuh juga harus tetap lebih rendah dari dosis toksis (Mareta, 2013).

\section{Kesesuaian Lama Penggunaan Antibiotik}

Lama penggunaan antibiotik umumnya minimal 5 hari, namun dikarenakan banyaknya masalah mengenai resistensi antibiotik dan adanya beberapa pertimbangan seperti pada pasien dengan resiko tinggi terkena ISPA, penggunaan antibiotik oral diperpanjang hingga rata-rata 10 hari. Sehingga dalam penelitian ini hasil dikelompokkan menjadi tiga 
kelompok. Kelompok pertama berdasarkan lama penggunaan 5 hari, dan kelompok kedua dengan lama penggunaan $<5$ hari hingga 10 hari (Mareta, 2013).

Kesesuaian lama penggunaan antibiotik kelompok pertama dalam penelitian ini menunjukkan hasil untuk pemakaian selama 5 hari sebesar 16,67 \% untuk kelompok kedua dengan pemakaian hingga 10 hari sebesar 7,14 \% sedangkan sisanya sebesar 76,19\% dengan lama penggunaan kurang dari 5 hari. Dari 42 sampel yang menggunakan antibiotik dengan lama penggunaan antibiotik $<5$ hari yaitu sebanyak 32 sampel atau dengan persentase 76,19 $\%$.

Berdasarkan hasil penelitian angka penggunaan antibiotik kurang dari 5 hari masih banyak terjadi. Frekuensi lama penggunaan antibiotik ini kurang sesuai, hal ini terjadi dikarenakan volume sediaan amoksisilin syrup yang tersedia di Puskesmas memang tidak mencukupi untuk penggunaan selama 5 hari dengan cara pemakaian menggunakan sendok teh sebanyak tiga kali dalam sehari. Namun apabila hal ini terjadi secara terus-menerus akan terjadi efek samping dari antibiotik yaitu resistensi dan efek lainnya dari penggunaan antibiotik dalam jangka yang panjang.

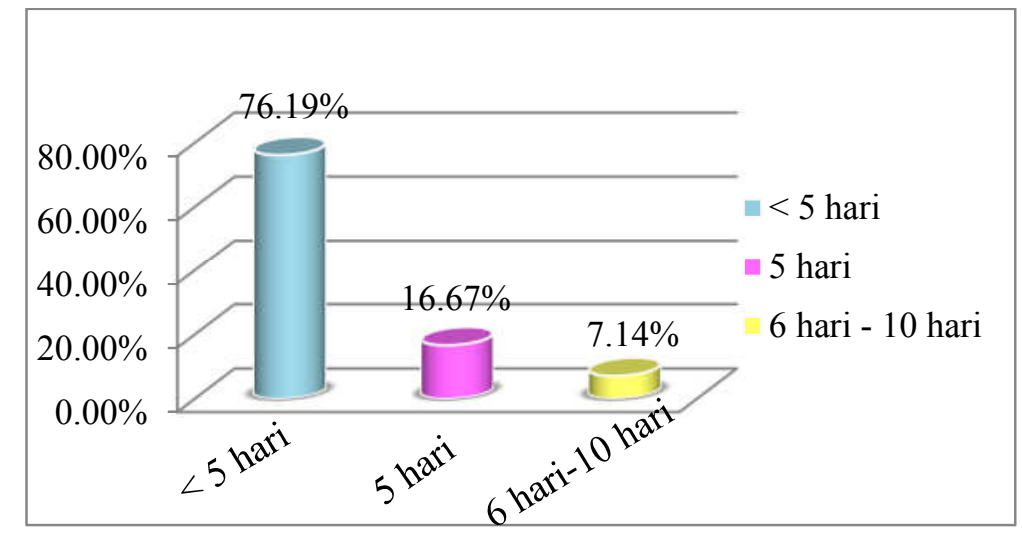

Gambar 8. Grafik distribusi Frekuensi Lama Penggunaan Antibiotik terhadap pasien balita ISPA bukan Pneumonia.

\section{KESIMPULAN}

Berdasarkan hasil penelitian evaluasi penggunaan antibiotik pada pasien balita dengan diagnosa ISPA bukan pneumonia yang dilakukan pada 223 pasien yang berusia 0 - 5 tahun dapat diambil kesimpulan bahwa persentase penggunaan antibiotik pada pasien ini mencapai $18,83 \%$ meski persentase mendekati angka indikator namun hal ini menunjukkan bahwa hasil penelitian masih memenuhi standar indikator kesalahan penggunaan antibiotik yaitu $\leq$ $20 \%$.

\section{DAFTAR PUSTAKA}

[CDC] Centers For Disease Control and Prevention.2003.Outbreaks.Of Severe Acute Respiratory Virus.worldwide.MMWR $2003 ; 52 ; 226$ - 8.

[Depkes] Departemen Kesehatan RI,2007.Pedoman Program Pemberantasan Penyakit ISPA Untuk Penanggulangan Pneumonia pada Balita.Jakarta : Dit.Jen.PPM-PLP.

[Dinkes] Dinas Kesehatan Provinsi Jawa Barat. 2011.Instrumen Akreditasi Puskesmas. Tim Akreditasi Puskesmas. Jawa Barat.

[Kemenkes] Kementerian Kesehatan RI. 2011. Modul Penggunaan Obat Rasional. Jakarta : Kementerian Kesehatan Republik Indonesia .

[Kemenkes] Kementerian Kesehatan RI. 2011. Pedoman Pelayanan Kefarmasian Untuk Terapi Antibiotik.Jakarta : Kementerian Kesehatan Republik Indonesia. 
Jurnal Inkofar * Volume 1 No. 1, Juli 2018 * ISSN: 2615-3645 (Print) / 2581-2920 (Online)

Tersedia secara online di: http://www.politeknikmeta.ac.id/meta/ojs/

Sutrisna B.2003. Efek Pemberian Ampisilin Terhadap ISPA Non Pneumonia Pada Balita Kekurangan Gizi. didalam : Abd.Harist musgany. Perpustakaan Universitas Indonesia:Jakarta. Diakses dari http://www.digilibUI.ac.id/opac/themes/libriz/detail.jsp?id=80058.

BMJ Group. 2009. British National Formulary For Children. London.

Gunawan. 2011. Farmakologi dan Terapan edisi ke lima. Jakarta : FKUI.

Katzung BG. 2004. Farmakologi Dasar dan Klinik Edisi 8. Diterjemahkan oleh bagian farmakologi fakultas kedokteran Universitas Indonesia.Jakarta: Universitas Indonesia.

Mareta, A. 2013. Skripsi :Pola Penggunaan Antibiotik pada Pasien Anak Dengan Diagnosa ISPA di Instalasi Rawat Jalan RS.Dr.H.Marzoeki Mahdi Bogor pada bulan Januari 2012 - Desember 2013.Bogor : STTIF.

Napitupulu D, Nuryadin A, Hikmawati P.2004. Prevalensi ISPA pada Balita Serta FaktorFaktor yang Berhubungan di RW 02 Kelurahan Rawasari Jakarta Pusat, Maret 2004. Tugas Program Kepaniteraan Ilmu Kesehatan Masyarakat Junior Fakultas Kedokteran UPN Veteran Jakarta.

Nasution K, Syafrullah MAR,dkk. 2005. Infeksi Saluran Pernafasan Akut pada Balita di Daerah Urban Jakarta.Fakultas Kedokteran Universitas Indonesia.Jakarta.

Neal, MJ. 2006.Medical Pharmacology at a Glance. Edisi 5.Penerbit Erlangga.h.81.

Sikolia DN, Mwololo K, Cherop H.2002. The Prevalence Of Acute Respiratory Infections and The Associated Risk Factors: A Study of Children Under Five Years of Age in Kibera Lindi Village, Nairobi, Kenya. J Natl Inst Public Health 2002;51:67-72.

Tritunggariani T. 2011.Faktor-faktor Yang Berhubungan Dengan Ketidakrasionalan Penggunaan Obat Pada ISPA Bukan Pneumonia di Puskesmas Perawatan di Kota Bekasi tahun 2011, Jakarta : Program pascasarjana Universitas Indonesia program Studi Ilmu Kesehatan Masyarakat.

World Health Organization.WHO.2007. Pencegahan dan Pengendalian ISPA yang Cenderung Menjadi Epidemi dan Pandemi di Fasilitas Pelayanan Kesehatan.Organisasi Kesehatan Dunia.Jenewa. 